\title{
Metastatic breast cancer presenting
fulminant hepatic failure: A case report and literature review
}

\author{
Malcolm S. Trimble, MD, Cameron N. Ghent, MD, David R. Grant, MD, Caroline A. Mclean, mD
}

ABSTRACT: A case of metastatic breast carcinoma presenting as fatal fulminant hepatic failure is presented. The patient did not have previously diagnosed breast cancer and presented with ascites, jaundice, abdominal pain, nausea, vomiting and hepatic encephalopathy. She died within four weeks of the onset. Seven similar cases previously reported are reviewed. Metastatic carcinoma should be considered in the differential diagnosis of fulminant hepatic failure. Can J Gastroenterol 1989;3(4):149-152

Key Words: Ascites, Breast carcinoma, Fulminant hepatic failure, Metastases

Le cancer métastatique du sein présentant les symptômes d'une insuffisance hépatique fulminante: Observation et revue de la littérature médicale

RESUME: On rapporte le cas d'un cancer métastatique du sein se présentant comme une insuffisance hépatique fulminante fatale. Le cancer du sein n'avait pas été diagnostiqué auparavant chez la patiente; elle présentait de l'ascite, de l'ictère, des douleurs abdominales, des nausées, des vomissements et une encéphalopathie hépatique. Le décès est survenu moins de quatre semaines après lapparition de ces symptômes. Sept cas semblables déjà rapportés sont examinés. L'éventualité d'un cancer métastatique devrait être considérée dans le diagnostic différentiel de l'hépatite hépatique fulminante.

Departments of Medicine, Surgery and Pathology, University Hospital, London, Ontario Correspondence and reprints: Dr C.N. Ghent, University Hospital, PO Box 5339, Londem, Ontario N6A 5 A5

Received for publication March 15, 1989. Accepted Jume 9, 1989
$\mathrm{T}$ HE LIVER IS A COMMON SITE FOR metastases of carcinoma, particularly from the lung, colon, pancreas and breast. In one autopsy series Ed. mundson and Craig (1) reported that $52 \%$ of patients have had some hepatic signs or symptoms referable to the metastases. However, fulminant hepatic failure as the initial clinical presentation of metastatic liver disease is rare. Since liver transplantation has become the accepted form of therapy for some causes of fulminant hepatic failure, it is important to identify this small group of patients to institute therapy (if available) directed at the malignancy and to exclude them as transplant candidates. A case of previously undiagnosed breast carcinoma presenting as fulminant hepatic failure is described.

\section{CASE PRESENTATION}

A 47-year-old white female was referred to the authors' hospital because 


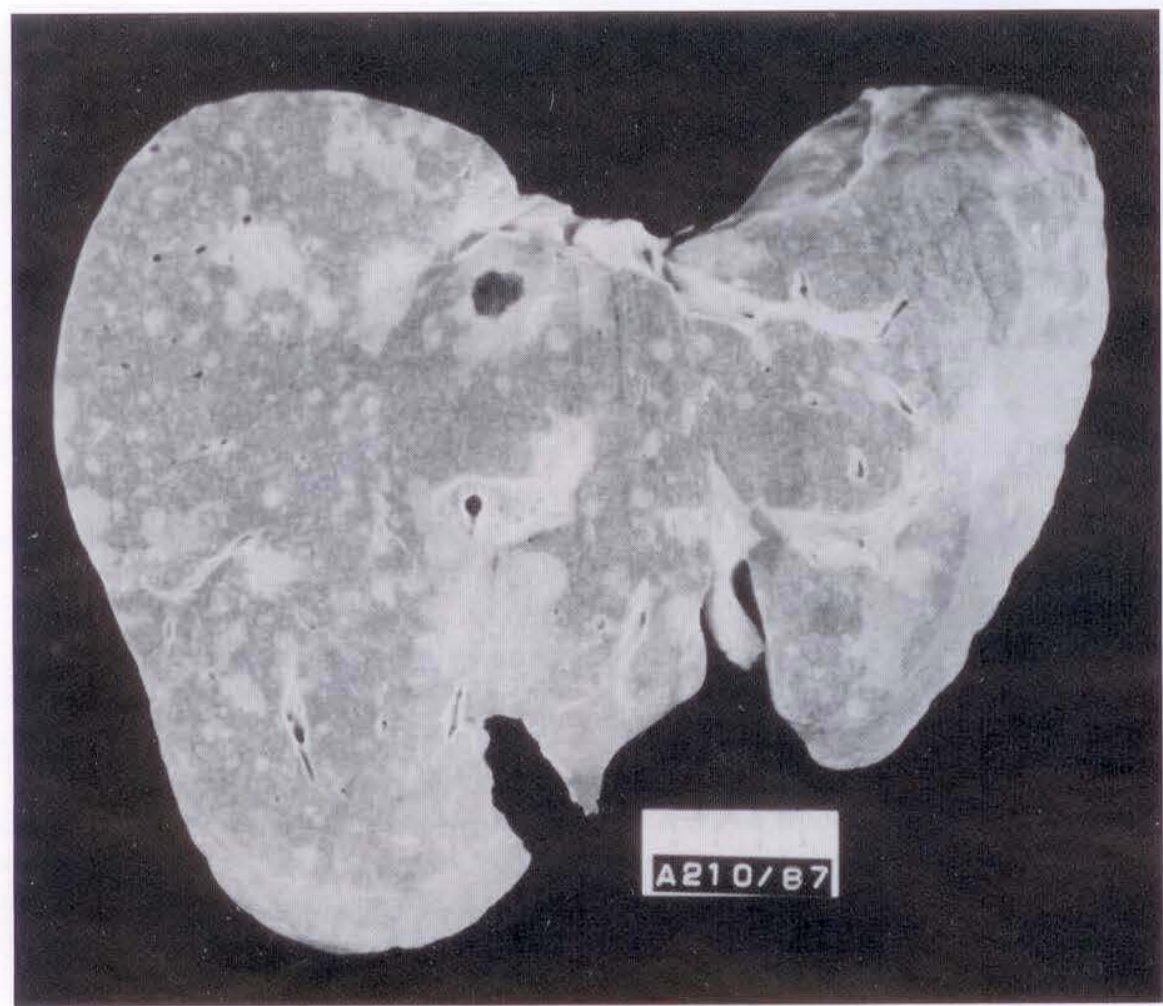

Figure 1) Gross appearance of cut surface of liver

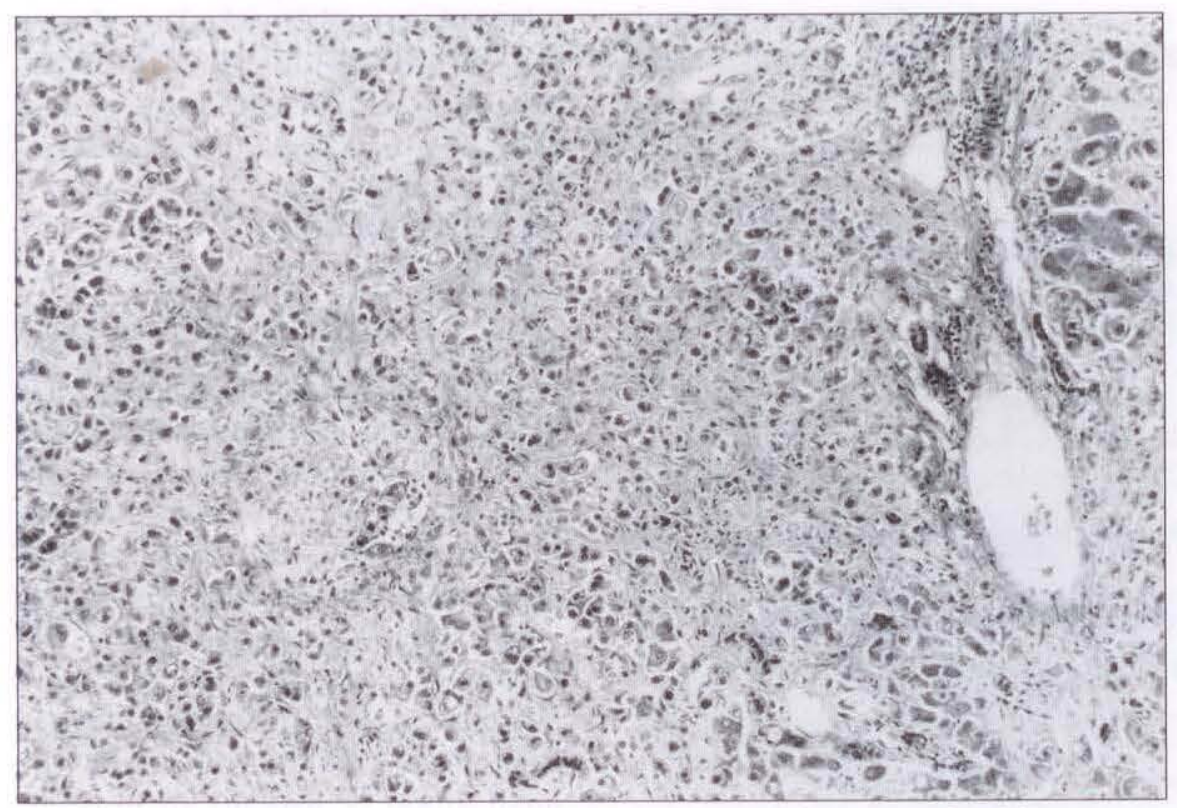

Figure 2) Microscopic appearance of representative section of liver. Note the diffuse tumour infiltration interspersed with normal hepatocytes, and extensive fibrosis. (Masson trichrome stain $x$ 200)

of fulminant hepatic failure. Four weeks prior to admission malaise and increasing right upper quadrant pain developed. Nausea and intermittent vomiting also developed. Two weeks later weight gain $(3 \mathrm{~kg})$, abdominal dis- tention and peripheral edema developed. There was no history of liver disease, hepatitis, jaundice, intravenous drug use, transfusion, alcohol abuse or exposure to toxins or medications. Past history included fibrocystic disease of both breasts with benign biopsies in 1984 , benign fine needle aspiration in 1987 and negative mammography in 1987.

On admission to another hospital the following laboratory results were obtained: aspartate aminotransferase $265 \mathrm{iu} / \mathrm{L}$; alanine aminotransferase 183 iu/L; alkaline phosphatase $290 \mathrm{iu} / \mathrm{L}$; gamma glutamyl transpeptidase 326 iu/L; bilirubin $56 \mu \mathrm{mol} / \mathrm{L}$; prothrombin time 14.6 s; partial thromboplastin time $66 \mathrm{~s}$; and total protein $56 \mathrm{~g} / \mathrm{L}$. Ultrasonography showed ascites, cholelithiasis and a $3 \mathrm{~cm}$ echogenic lesion in the right lobe felt to be a hemangioma. Hepatic venography excluded acute Budd-Chiari syndrome, with normal hepatic veins demonstrated. A percutaneous liver biopsy was attempted but no tissue was obtained.

The patient was transferred to the authors' centre. She was drowsy and confused with asterixis present on arrival. Vital signs were stable and she was afebrile. No stigmata of chronic liver disease were apparent. Ascites was present without abdominal tenderness or abdominal wall venous collaterals. The liver was palpably enlarged $(18 \mathrm{~cm})$ with a firm edge. Pitting edema was present to the knees. A small, firm, irregular mass was palpable in the right breast with localized right axil. lary lymphadenopathy.

Initial lab work revealed: sodium $126 \mathrm{mmol} / \mathrm{L}$; potassium $5.5 \mathrm{mmol} / \mathrm{L}$; chloride $100 \mathrm{mmol} / \mathrm{L}$; carbon dioxide $14.5 \mathrm{mmol} / \mathrm{L}$; urea $10.2 \mathrm{mmol} / \mathrm{L}_{\text {; }}$ creatinine $192 \mu \mathrm{mol} / \mathrm{L}$; bilirubin 166 $\mu \mathrm{mol} / \mathrm{L}$; albumin $29.6 \mathrm{~g} / \mathrm{L}$; total protein $58.3 \mathrm{~g} / \mathrm{L}$; prothrombin time $14 \mathrm{~s}$; partial thromboplastin time $95 \mathrm{~s}$ (reduced to 14 and $69.5 \mathrm{~s}$, respectively with vitamin $\mathrm{K}$ ); leukocytes $22.1 \times 10^{9} \mathrm{~L}$; hemoglobin 113 $\mathrm{g} / \mathrm{L}$; platelets $193 \times 10^{9} / \mathrm{L}$; and fragmentation, polychromatic and nucleated red blood cells (6/100 white blood cells) were seen on the peripheral blood smear. Aspartate aminotransferase was $46 \mathrm{iu} / \mathrm{L}$; alanine aminotransferase 109 $\mathrm{iu} / \mathrm{L}$; alkaline phosphatase $186 \mathrm{iu} / \mathrm{L}$; gamma glutamyl transpeptidase 412 $\mathrm{iu} / \mathrm{L}$; serum hepatitis B surface antigen was negative; $1.5 \mathrm{~L}$ of grossly bloody ascites were removed with the follow. 
Symptoms and signs on admission of previously published cases of acute liver failure secondary to breast carcinoma

\begin{tabular}{|c|c|c|c|c|c|c|c|c|}
\hline \multicolumn{9}{|c|}{ Case (reference) } \\
\hline & $1(2)$ & $2(2)$ & $3(2)$ & $4(3)$ & $5(4)$ & $6(5)$ & $7(8)$ & $8^{\circ}$ \\
\hline Age (years) & 37 & 58 & 55 & 57 & 27 & 44 & 46 & 47 \\
\hline $\begin{array}{l}\text { Duration } \\
\text { of illness (weeks) }\end{array}$ & 4 & 5 & 4 & 3 & 3 & 13 days & 8 & 4 \\
\hline Jaundice & + & + & + & + & + & + & + & + \\
\hline Abdominal pain & + & + & - & + & + & + & + & + \\
\hline $\begin{array}{l}\text { Nausea and } \\
\text { vomiting }\end{array}$ & + & + & - & - & + & + & - & + \\
\hline Ascites & + & - & - & - & + & - & + & + \\
\hline Encephalopathy & + & + & + & + & - & - & - & + \\
\hline $\begin{array}{l}\text { Past breast } \\
\text { cancer }\end{array}$ & Yes & Yes & Yes & No & Yes & Yes & Yes & No \\
\hline Bilirubin & 135 & 176 & 50 & 227 & 55 & 35.2 & 115 & 166 \\
\hline AST (iu/L) & 180 & 149 & 74 & 507 & 830 & - & 339 & 46 \\
\hline $\operatorname{AP}(i u / L)$ & 450 & 1730 & 1945 & 1011 & 375 & $1.7 \times$ normal & $1.6 \times$ normal & 186 \\
\hline PI & $14 \%$ & Normal & $10 \%$ & $38 \mathrm{~s}$ & $17.3 \mathrm{~s}$ & $18.9 \mathrm{~s}$ & $75 \%$ & $14 \mathrm{~s}$ \\
\hline Albumin & - & 26 & - & - & 28 & 28 & 27 & 29 \\
\hline Pathology & $\begin{array}{l}\text { Widespread } \\
\text { metastases. } \\
\text { Diffuse infiltration } \\
\text { of liver with necros }\end{array}$ & $\begin{array}{l}\text { As case } 1 \\
\text { sis }\end{array}$ & $\begin{array}{l}\text { None obtained. } \\
\text { Recovered with } \\
\text { chemo-and } \\
\text { radiotherapy }\end{array}$ & $\begin{array}{l}\text { Widespread } \\
\text { metastases. } \\
\text { Liver } 1960 \mathrm{~g} \text {. } \\
\text { infiltration of } \\
\text { vessels. sinusoids } \\
\text { lymphatics. } \\
\text { Death from } \\
\text { variceal hemorrh }\end{array}$ & $\begin{array}{l}\text { Diffuse } \\
\text { sinusoidal } \\
\text { infiltration with } \\
\text { fibrosis. massive } \\
\text { necrosis. } \\
\text { Liver } 1500 \mathrm{~g} \\
\text { age }\end{array}$ & $\begin{array}{l}\text { Widespread } \\
\text { metastases } \\
\text { Liver } 1800 \mathrm{~g} \text {. } \\
\text { diffuse sinusoidal } \\
\text { infiltration }\end{array}$ & $\begin{array}{l}\text { Widespread } \\
\text { metastases. } \\
\text { Liver } 1435 \mathrm{~g} \text {. } \\
\text { Diffuse vascular } \\
\text { and lymphatic } \\
\text { infiltration. } \\
\text { Intense fibrosis }\end{array}$ & $\begin{array}{l}\text { As } \\
\text { case } \\
7 \\
7\end{array}$ \\
\hline $\begin{array}{l}\text { Diagnosis } \\
\text { suspected }\end{array}$ & Yes & Yes & Yes & No & & No & & Yes \\
\hline
\end{tabular}

- Present case: AP Alkaline phosphatase: AST Aspartate aminotransferase: PT Prothrombin time

ing results: leukocytes $6 \times 10^{9} / \mathrm{L}(48 \%$ polymorphonuclear leukocytes), red blood cells $91 \times 10^{9} / \mathrm{L}$ and the cytology was negative.

Despite treatment for infected ascites and liver failure with intravenous cefoxitin, albumin, flesh frozen plasma, vitamin $K$ and lactulose, the patient's condition worsened. A needle biopsy of the right breast mass was performed under local anesthesia. Within $24 \mathrm{~h}$ she was transferred to the intensive care unit because of hypotension, oliguria and respiratory failure.

Repeat abdominal ultrasonography revealed the echogenic right lobe lesion seen earlier, ascites and a diffusely inhomogeneous liver parenchyma. The biopsy of the right breast was reported to show adenocarcinoma. She died shortly thereafter of multiple organ failure. The entire duration of her illness was four weeks.

\section{AUTOPSY}

The autopsy revealed infiltrating ductal carcinoma of the right breast with extensive metastases to regional nodes, the left breast, liver, spleen, bone marrow and lymphangitic carcinomatosis of the lung. Microscopic metastases were present in brain, epicardium, thyroid, adrenal gland, ovary and pancreas.

The liver weighed $1690 \mathrm{~g}$ and was diffusely yellow with large areas of tan mottling (Figure 1). Extensive tumour infiltration of portal tracts, lymphatics and sinusoids was present (Figure 2). Maximal involvement of the lobule was seen around the central vein. Marked desmoplastic reaction to the tumour was present. A typical cavernous hemangioma was identified in the right lobe.

\section{DISCUSSION}

The patient exhibited a rapid downhill course with acute liver failure and died four weeks after the onset of the first symptoms. Without the breast mass and subsequent confirmation of adenocarcinoma by needle biopsy, the etiology of her liver failure would have remained unclear. Seven previously published cases of acute liver failure secondary to breast carcinoma were available for review and are summarized in Table $1(2-5,8)$. As with the present patient, right upper quadrant abdominal pain (five of seven) and jaundice (six of seven) were common presenting features. These clinical features are common along with ascites in all types of metastatic liver disease (6) and liver disease in general. The amount of tumour replacement required to produce symptoms is variable but in one series of patients with hepatic coma all had greater than 50\% replacement (7).

In four of seven patients the diagnosis was unclear and in two of these it was totally unsuspected. In one of these patients the primary breast cancer was occult and in the other the diagnosis was acute hepatitis despite a mastectomy four months earlier (5). Pathology was available in six of seven patients who died. All showed extensive sinusoidal, vascular and lymphatic infiltration by tumour with variable degrees of hepatic necrosis. Those with marked necrosis (three patients) may have suffered terminal hypotension or 
had tumour compromising hepatic vascular supply.

Six of 20 cases in the review of diffuse intrasinusoidal metastatic disease were due to breast cancer but the clinical details were insufficient, apart from the index case, to be included here as fulfilling criteria for fulminant hepatic failure (5). Variable degrees of fibrosis can accompany the tumours but it can be so intense as to mimic cirrhosis with portal hypertension and lead to variceal hemorrhage as the terminal event (8). Fulminant hepatic failure has been reported with small cell car-

\section{REFERENCES}

1. Edmundson HA, Craig JR. Neoplasms of the liver. In: Schiff, ed. Diseases of the Liver, 6th edn. Philadelphia: Lippincott Co, 1987:1109-58.

2. Razenberg PPA, Taal BG, Albus-Lutter CE. Hepatic failure due to liver metastases in breast cancer. Neth J Med 1985:28:295-8.

3. Morrison WL, Pennington CR. Liver metastases from an occult breast carcinoma presenting as acute fulminant hepatic failure. $\mathrm{Br} J$ Clin Prac 1984:38:2\%3-4.

4. Schneider R, Cohen A. Fulminant hepatic failure complicating metastatic breast carcinoma. South Med J 1984:77:84-6. cinoma of lung, adenocarcinoma of pancreas and primary malignant hemangioendothelioma of liver $(9-12)$.

Early diagnosis is essential to offer aggressive chemotherapy of responsive tumours which may alter outcome (2) and to exclude these patients as transplant recipients. This may be difficult if the primary lesion is occult and the clinical picture unclear. These patients are often unsuitable for percutaneous liver biopsy (ascites, coagulopathy) so transvenous biopsy should be considered.

Sherlock (13) has summarized well

5. Smith JC. Diffuse intrasinusoidal metastatic cancer of the liver. Ann Intern Med 1961;54:104-13.

6. Fenster LF, Klatskin G. Manifestations of metastatic tumors of the liver: A study of 81 patients subjected to needle biopsy. Am J Med 1961;31:238-48.

7. Eras P, Sherlock P. Hepatic coma secondary to metastatic liver disease. Ann Intern Med 1971;74:581-3.

8. Borja ER, Hori JM, Pugh RP. Metastatic carcinomatosis of the liver mimicking cirrhosis: Case report and review of the literature. Cancer 1975;35:445-9.

9. Harrison HB, Middleton HM III, Crosby JH, Dasher MN Jr. Fulminant hepatic failure: An unusual presentation of metastatic liver disease. the approach to the patient with fulminant hepatic failure. The present authors emphasize the need to consider metastatic disease in the differential diagnosis of fulminant hepatic failure From this review an unusually low level of serum transaminases with elevation of alkaline phosphatase in the setting of fulminant hepatic failure suggests metastatic carcinoma as the etiology, although alcoholic liver disease and Wilson's disease may also present as fulminant hepatic failure with transaminase levels less than 10 times normal.

Gastroenterology 1981;80:820-5.

10. Krauss EA, Ludwig PW, Sumner HW. Metastatic carcinoma presenting as fulminant hepatic failure. Am ] Gastroenterol 1979;72:651-4.

11. Malloy TB, Castleman B, Parris EE. Case records of the Massachusetts General Hospital (Case No, 32401). N Engl J Med 1946;235:521-4.

12. Stein AM, Fawaz K, Tabriz A, Blanchard R, Hou S. Multifocal malignant hemangioendothelioma presenting as acute hepatitis. Am J Gastroenterol 1977;67:370-4.

13. Sherlock S. Acute (fulminant) hepatic failure. In: Diseases of the Liver and Biliary System, 7th edn. Boston:Blackwell Scientific Publications, 1985: 110-3. 


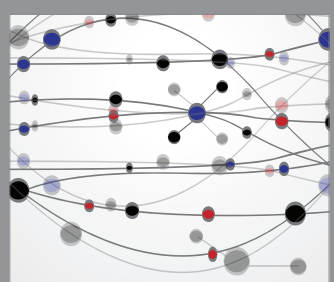

The Scientific World Journal


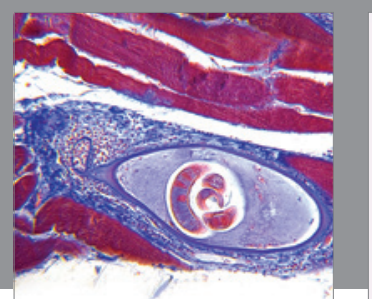

Gastroenterology Research and Practice

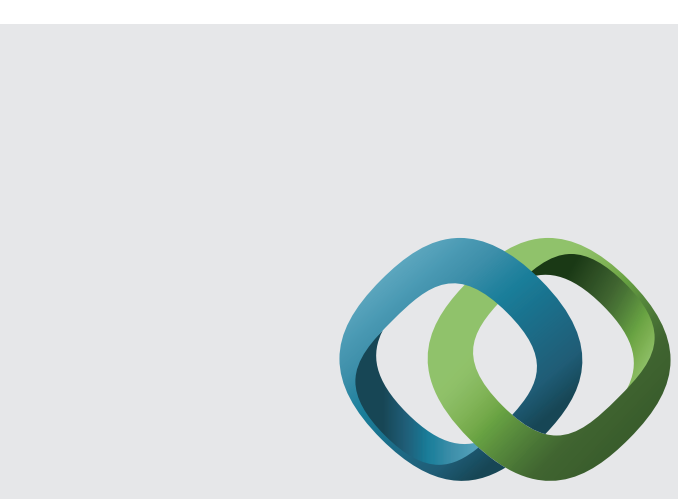

\section{Hindawi}

Submit your manuscripts at

http://www.hindawi.com
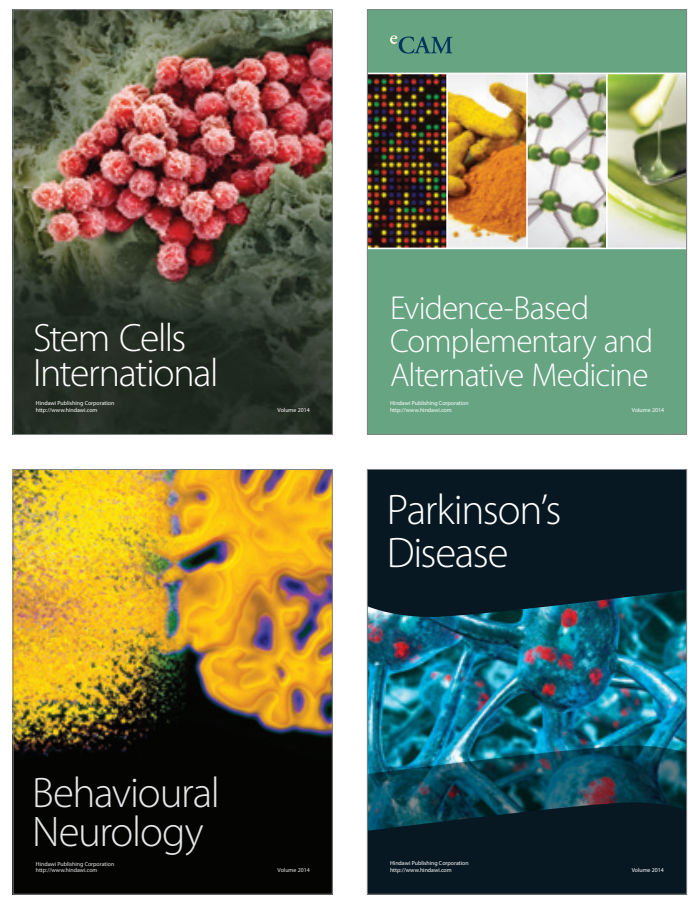


Disease Markers
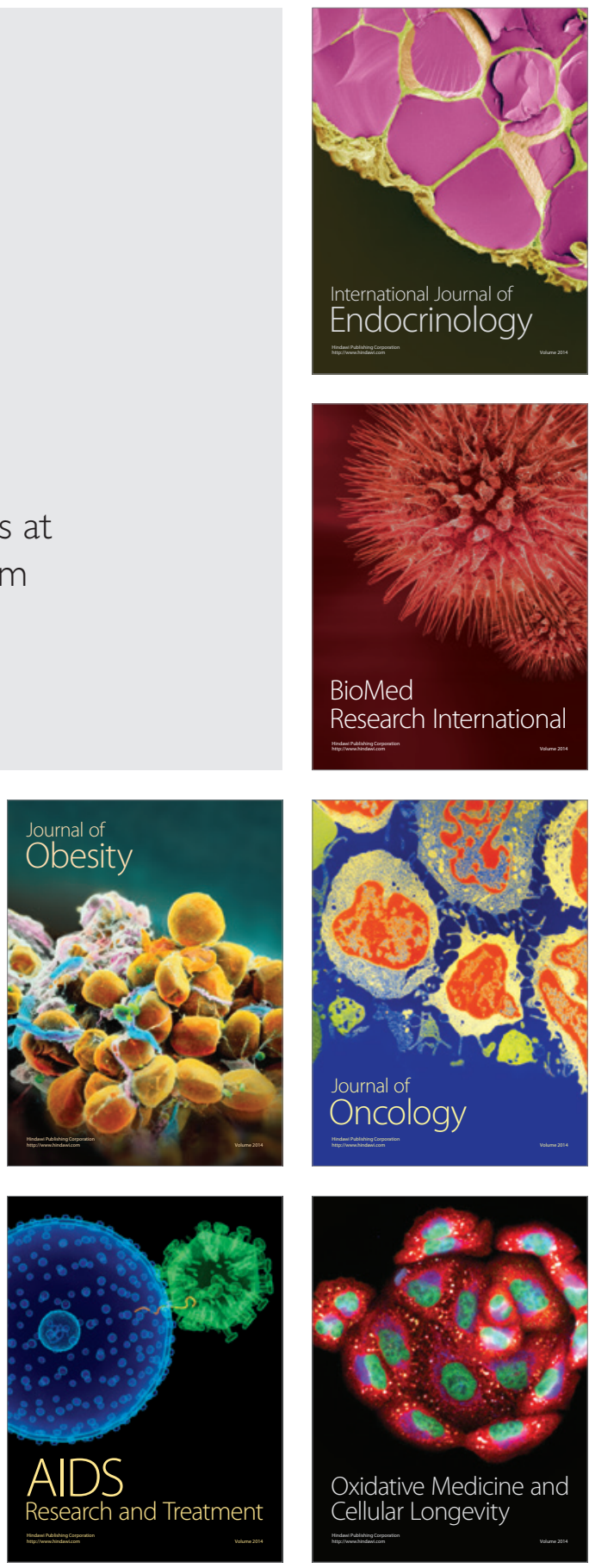